Entretelones de santuarios católicos: creadores de símbolos, milagros y devociones en Latinoamérica (entre la colonia y el siglo XX)

Julia Costilla

Relaciones, 46(2), e 025, julio-diciembre 2021

ISSN 1852-1479 | https://doi.org/10.24215/18521479e025

https://revistas.unlp.edu.ar/relaciones

ISSN 0325-2221 (versión impresa)

Sociedad Argentina de Antropología (SAA)

Buenos Aires I Argentina

\title{
ENTRETELONES DE SANTUARIOS CATÓLICOS: CREADORES DE SÍMBOLOS, MILAGROS Y DEVOCIONES EN LATINOAMÉRICA (ENTRE LA COLONIA Y EL SIGLO XX)
}

Julia Costilla*

Fecha de recepción: 14 de diciembre de 2020

Fecha de aceptación: 8 de agosto de 2021

\section{RESUMEN}

El trabajo aborda comparativamente el surgimiento de tres santuarios católicos latinoamericanos: el de la Virgen de Copacabana y el del Señor de los Milagros de Lima, ambos de origen colonial (Virreinato peruano), y el de la Virgen del Rosario de San Nicolás (Argentina), originado en las últimas décadas del siglo XX. Desde una perspectiva antropológica, combinando trabajo de archivo con enfoque etnográfico, se analizan las principales acciones y motivaciones que contribuyeron a consolidar cada uno de los santuarios. ¿Quiénes fueron los productores -materiales y simbólicos-de estas imágenes católicas y en qué circunstancias actuaron? ¿De qué manera surgieron las devociones en torno a ellas? ¿Cuál fue el papel de los sucesos milagrosos en la afirmación de los cultos? Me propongo examinar la posibilidad de reconocer regularidades y lógicas comunes en estos procesos, analizando hasta qué punto remiten a factores contextuales o a dinámicas propias de la construcción de santuarios católicos.

Palabras clave: santuarios-cultos católicos-símbolos religiosos-milagros-Latinoamérica

\footnotetext{
* Consejo Nacional de Investigaciones Científicas y Técnicas, Universidad de Buenos Aires, Facultad de Filosofía y Letras, Instituto de Ciencias Antropológicas. E-mail: juliacostilla@hotmail.com
} 
Relaciones de la Sociedad Argentina de Antropología 46 (2), julio-diciembre 2021: 699-723

BACKSTAGE OF CATHOLIC SANCTUARIES: CREATORS OF SYMBOLS, MIRCALES AND WORSHIPS IN LATIN AMERICA (BETWEEN COLONIAL TIMES AND XX ${ }^{T H}$ CENTURY)

\section{ABSTRACT}

This paper comparatively addresses the emergence of three Latin-American Catholic sanctuaries: Virgen de Copacabana and Señor de los Milagros de Lima, both of colonial origin (Peruvian Viceroyalty), and Virgen del Rosario of San Nicolás (Argentina, since 1983). Using an anthropological perspective, through archive research with an ethnographic approach, the primary actions and motivations that helped consolidate these sanctuaries are analyzed. Who were the material and symbolic producers of these Catholic images and in which circumstances did they act? How did they become places of devotion? Which was the role of the miracles in cult consolidation? I will examine the possibility of recognizing regularities and common logics in these processes, analyzing to what extent they express either contextual factors or Catholic sanctuaries typical dynamics.

Keywords: sanctuaries - catholic cults - religious symbols -miracles - Latin America

\section{INTRODUCCIÓN}

En buena parte de las ciudades y localidades latinoamericanas, la historia de la evangelización dejó su marca en la presencia de reconocidos santuarios católicos. Allí se congregan año a año devotos de diversas procedencias que, con distintos objetivos (sobre todo pedidos y agradecimientos), buscan acercarse a las imágenes sacralizadas. Más allá de las variadas motivaciones de sus fieles y peregrinos, la veneración que reciben determinadas imágenes reconocidas como milagrosas implica que detrás de esas prácticas devotas subyace el proceso de construcción de un objeto de culto particular, entendido aquí como símbolo religioso. Para profundizar en esos procesos y sistematizarlos evaluando regularidades -o singularidades-, abordaré en estas páginas el surgimiento de tres santuarios católicos latinoamericanos de manera comparativa.

Esta tarea se enmarca en una investigación doctoral que analizó comparativamente tres cultos en larga duración (entre la colonia y la actualidad). Desde el inicio nos movilizó la pregunta sobre cómo opera el milagro cristiano en la dinámica social, entendiéndolo como símbolo religioso construido en un determinado contexto (Costilla 2014). Específicamente, nos interesó examinar cuál ha sido el papel de los milagros en la construcción de cultos católicos latinoamericanos, desde qué lugares y con qué objetivos han sido esgrimidos. En esa línea, planteamos como objeto de nuestra observación etnográfica el surgimiento y desarrollo de cultos a imágenes milagrosas dentro del catolicismo latinoamericano en distintas épocas. Y desde allí, valoramos la potencialidad del método comparativo, considerando sus alcances, limitaciones, riesgos y exigencias en tanto instrumento técnico útil y manejable (Bloch 1999; Kuper 2002; Coelho Prado 2012; Costilla 2014; Caballero Escorcia 2015). Una antropología histórica comparada (Costilla 2016) nos permitiría esclarecer procesos singulares a partir de comprobar ciertas conexiones probables entre fenómenos, ponderar con mayor precisión la influencia de variables contextuales y proponer ciertas regularidades (Costilla 2014:70-73).

El desafío fundamental fue, entonces, la selección de los casos para analizar. Contemplando nuestras preguntas e intereses, en primer lugar definimos como unidades de comparación santuarios católicos oficiales hispanoamericanos, es decir con tres grandes atributos comunes: (a) remitir a un horizonte cultural católico de raíz hispana (entre otras tradiciones posibles); (b) haber sido oficializados y, por ende, involucrar a las jerarquías eclesiásticas -para analizar articulaciones y tensiones con discursos/prácticas devocionales-; y (c) extenderse dentro de un área geohistórica 
común, ligada al Virreinato peruano, aunque luego avanzaríamos al período republicano debido a nuestro interés por llegar a la actualidad. En este sentido, otro de los criterios fue que los cultos siguieran vigentes; sumado esto a que tuvieran una magnitud y extensión considerables y a que se vincularan con identidades políticas oficiales (a nivel municipal y/o nacional). A la vez, fue condicionante la disponibilidad de materiales para investigar su origen y desarrollo, en especial documentación para analizar milagros.

Como estos criterios no llegaron a acotar lo suficiente el abanico de casos posibles, para proponer una comparación manejable seleccionamos tres santuarios de manera operativa: dos de ellos representativos de Bolivia y Perú, y uno de Argentina (Costilla 2014). El más antiguo fue el de la Virgen de Copacabana, con una imagen de la Candelaria tallada por un indígena local en 1583. Le siguió el del Señor de los Milagros de Lima, con un mural de Cristo crucificado con más de 360 años de antigüedad que, según coinciden las fuentes, fue pintado por un negro ${ }^{1}$ de la ciudad en 1651. Por último, se trabajó con la Virgen del Rosario de San Nicolás, venerada desde 1983 a partir de un resonado fenómeno de apariciones y mensajes marianos.

Este tercer caso se presentó desde el inicio como polémico y riesgoso, comprometiendo la comparabilidad en términos cronológicos (Olabárri en Caballero Escorcia 2015): un culto surgido a fines del siglo XX frente a dos de origen colonial. Sin embargo, sostuvimos su inclusión por dos motivos. Primero, por lo significativo del caso: un santuario con veinticinco años de trayectoria, pero posicionado como segundo centro de peregrinación más importante de Argentina (luego de Luján) (Flores 2013). Además, porque consideramos que, precisamente al ubicarse en un contexto social y temporal disímil, enriquecería la contrastación empírica exponiendo -casi como un contra-caso- posibles regularidades transtemporales y habilitando observaciones más generales sobre el fenómeno de los santuarios católicos.

De esta manera, propusimos una comparación antropológica que podríamos caracterizar como regional a gran escala, de horizonte amplio en términos espaciales y sobre todo temporales, porque comprendió la larga duración y por la distancia entre los casos. Las imágenes de culto son distintas, un Cristo y dos advocaciones marianas, y los santuarios se diferencian en sus escenarios socio-políticos de surgimiento. Contrastan un pueblo de indios andino, una ciudad que fue sede arzobispal y capital virreinal -con población multiétnica y alta presencia africana-, y una localidad ubicada en la provincia argentina de Buenos Aires -con población criolla e inmigración italiana desde fines del siglo XIX. Sobre todo en este trabajo, por enfocarse en el origen de los cultos, nos moveremos constantemente entre períodos bien disímiles: la colonia temprana (siglos XVI-XVII) y fines del siglo XX. No obstante, sin seguir un sincronismo histórico, procuramos aplicar un procedimiento sistemático y riguroso sustentado en un marco conceptual preciso y en variables semejantes.

Además de los aspectos comunes ya expuestos como criterios de selección, los casos comparten, en tanto santuarios católicos, una serie de elementos: una imagen sagrada, narrativas sobre milagros, agentes administradores del templo y el culto, peregrinos/promesantes, prácticas devotas, una fecha sacralizada y festejos asociados. Entendidos como atributos o puntos de comparación (Caballero Escorcia 2015), tales elementos permitieron definir las preguntas y ejes que abordará este trabajo. ¿Quiénes fueron los productores - materiales y simbólicos- de las imágenes y en qué circunstancias actuaron? ¿Cómo fue siendo creado cada uno de los símbolos religiosos dominantes en esos santuarios y cómo llegaron a consolidarse las devociones en torno a ellos? ¿Cuál fue el papel de los sucesos milagrosos en la afirmación de los cultos? ¿Es posible reconocer regularidades en esas historias fundantes y proponer a algunas como transtemporales? ¿Se revelan rasgos específicos para la construcción de cultos latinoamericanos? En el título de este artículo me refiero a "entretelones" de santuarios porque me interesó reconstruir el trasfondo o "detrás de escena" de esos templos hoy consolidados. Y a través de la comparación, iluminar sobre características específicas de fenómenos comunes. 
La metodología empleada para desarrollar mi objetivo combinó el enfoque etnográfico con el trabajo de campo y archivo; así, los procesos y acontecimientos históricos fueron interpretados desde una mirada antropológica, orientada a recuperar significados y representaciones nativas (Lorandi 2012; Costilla 2015). Las fuentes de información han sido diversas: desde documentos inéditos y publicaciones antiguas, para los casos coloniales (dispersos en distintos repositorios de las ciudades de Lima, Copacabana, La Paz y Sucre), hasta entrevistas y registros de campo (entre los años 2008 y 2013) para el caso contemporáneo de San Nicolás, donde contamos además con publicaciones periodísticas y variados materiales de difusión sobre el culto. A su vez, como se expondrá a lo largo del análisis, parto de un marco teórico nutrido por aportes de la antropología, la historia y la sociología de la religión, en especial, investigaciones sobre prácticas y símbolos vinculados al catolicismo. ${ }^{2}$ Sin dudas, la bibliografía sobre santuarios fue reveladora para afinar los ejes y técnicas de la comparación. Proporcionó elementos de inspiración y permitió desarrollar una sensibilidad particular (Bloch 1999) para definir variables de análisis, examinar las fuentes, plantear hipótesis e interpretar los datos. Es decir que complementó la comparación sistemática de los casos elegidos.

En el primer apartado se presenta una contextualización general sobre el surgimiento de los tres cultos y la historia particular de cada santuario, para luego precisar las herramientas teórico-metodológicas que permitieron analizar esos hechos y procesos. En los siguientes tres apartados se desarrolla, de manera sucinta, el análisis comparativo de acuerdo a tres grandes ejes: (i) la producción de las imágenes -quiénes y en qué circunstancias-, (ii) el origen de la devoción hacia esas imágenes $y$, (iii) los sucesos milagrosos que fueron decisivos en esos surgimientos. Aunque estos ejes están absolutamente entrelazados, realizamos una distinción operativa a fin de ordenar la comparación y exponer más claramente las semejanzas y diferencias entre los casos. Me propongo así examinar la posibilidad de reconocer regularidades y lógicas comunes en la construcción de estos santuarios, analizando hasta qué punto remiten a factores contextuales o a dinámicas propias de la construcción de santuarios católicos.

\section{CONTEXTOS Y PROBLEMATIZACIÓN INICIAL}

La base general de estos cultos es la evangelización de América, en dos momentos históricos distintos. Los casos de Copacabana y Lima refieren a la cristianización de indios y negros durante la Colonia, bajo el llamado "régimen de cristiandad" y las pautas del Patronato Regio (Di Stéfano y Zanatta 2000; Roux 2014). El de San Nicolás, por su parte, remite a una evangelización renovada dentro del contexto republicano secularizado: en ámbitos diocesanos tradicionales, como en este caso -con población mayormente criolla-, la meta era "reconquistar" la sociedad. Ambos procesos, además, corresponden a escenarios político-económicos distantes: el primero asociado al gobierno colonial español, dentro del Virreinato peruano, y el segundo, a fines del siglo XIX, paralelo al avance de los Estados-nación liberales y del capitalismo mundial, lo cual implicó un reposicionamiento para la Iglesia Católica (Di Stéfano y Zanatta 2000; Nicoletti 2008; Roux 2014). Mientras estos marcos definen las circunstancias históricas de las que partimos en cada culto, los hechos registrados en las fuentes suelen involucrar también aspectos legendarios. Estos últimos, como veremos, serán igualmente relevantes para identificar regularidades en los sucesos fundantes de distintos santuarios católicos.

El caso de la Virgen de Copacabana nos ubica en el pueblo de reducción homónimo a orillas del lago Titicaca, dentro del antiguo Collasuyo -cuadrante sur del Tawantinsuyo-y de la jurisdicción del Virreinato Peruano. En 1582, un nativo local llamado Francisco Tito Yupanqui, descendiente de la elite incaica, se dispuso a tallar una imagen de bulto de la Virgen de la Candelaria para que su pueblo pudiera fundar una cofradía en su nombre. Aunque su obra fue originalmente rechazada 
por distintas autoridades coloniales y parte de los habitantes de Copacabana, la imagen terminó siendo aceptada luego de una serie de manifestaciones y entronizada en la iglesia local en 1583. En 1588 las autoridades reales encargaron el culto a los sacerdotes agustinos y éstos lograron consolidarlo hacia 1614, gestionando la edificación de un santuario y difundiendo la Virgen a nivel regional y ultramarino (Costilla 2010, 2014).

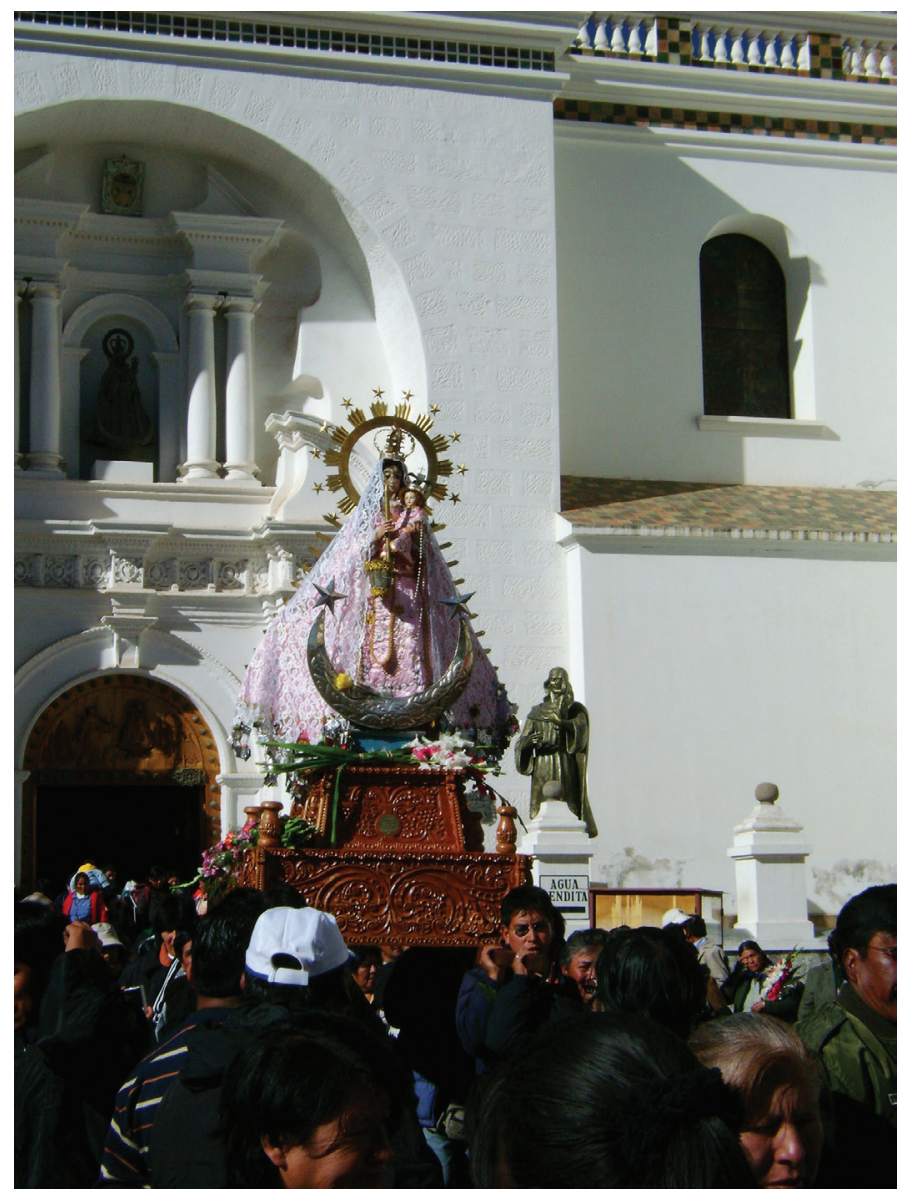

Figura 1. Virgen de Copacabana en su santuario (detrás, a la derecha, puede verse estatua de Yupanqui) (fotografía de la autora, 5/08/2010)

El Señor de los Milagros de Lima nos traslada a la ciudad que fue sede central del Virreinato Peruano. En el barrio conocido como Pachacamilla, a mediados del siglo XVII (1651) un feligrés de origen africano, integrante de una cofradía de negros, pintó una imagen de Cristo crucificado en una de las paredes del recinto donde se reunían. La devoción fue creciendo entre los fieles de parroquias vecinas, pero las autoridades limeñas rechazaron inicialmente a la imagen. La aceptación llegó en el año 1671, tras una manifestación reconocida como milagrosa: se realizó la primera misa ante el Cristo con presencia de los más altos poderes coloniales, incluido el Virrey, y el Arzobispo designó un mayordomo para la capilla. En 1687, a raíz de un fatídico terremoto en la ciudad, organizaron la primera procesión rogativa con una réplica de la imagen y en $1702 \mathrm{su}$ santuario fue encomendado a una congregación de religiosas (Nazarenas Carmelitas). Con el culto ya consolidado, en 1715 el Cabildo limeño juró al Cristo como patrono de la ciudad (Costilla 2015). 


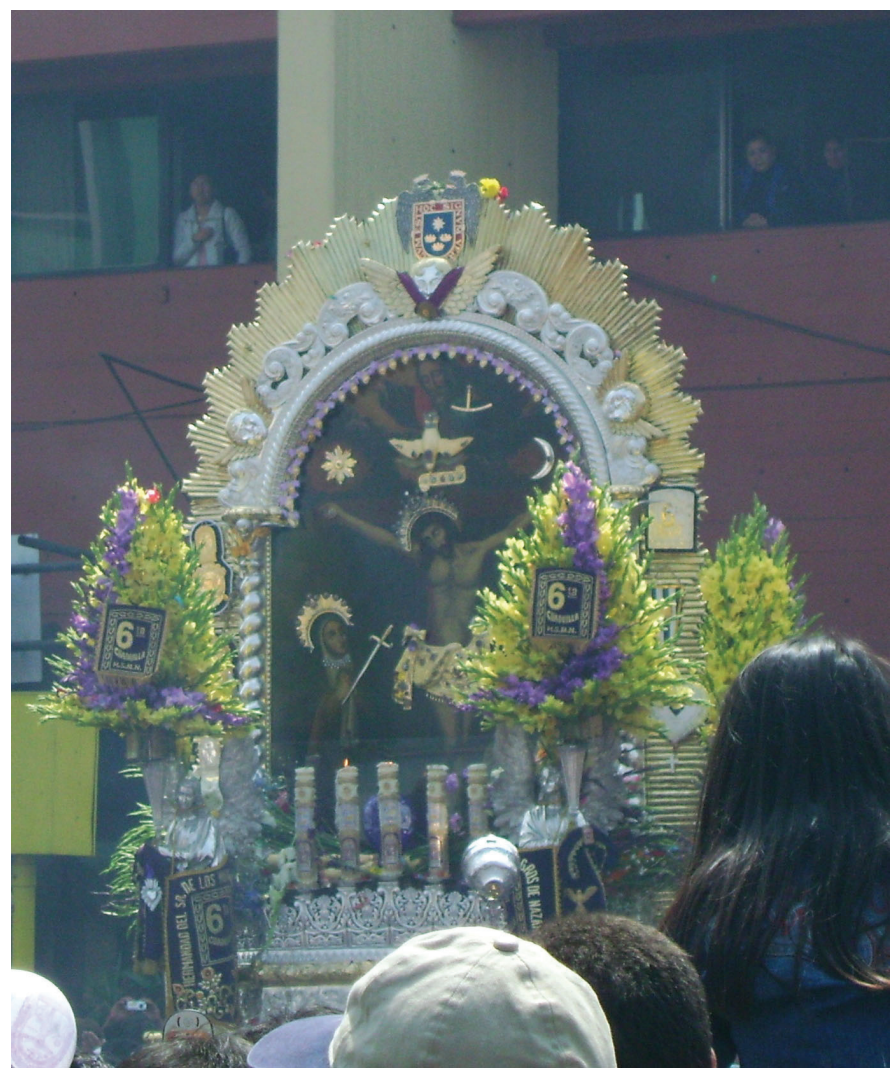

Figura 2. Imagen procesional del Señor de los Milagros (fotografía de la autora, 18/10/2008)

El santuario de la Virgen del Rosario de San Nicolás, dentro de la República Argentina, posee una trayectoria relativamente breve y reciente. El 25 de septiembre de 1983, una vecina de la ciudad comenzó a experimentar una serie de apariciones y mensajes marianos que movilizaron la entronización de una imagen de la Virgen del Rosario anteriormente guardada en la Catedral local. En pocos meses se fueron multiplicando los devotos que se acercaban a venerarla y se construyó un pequeño oratorio en el sitio que la propia Virgen habría indicado para la instalación de su santuario. El Obispado de San Nicolás gestionó con el Municipio la donación de los terrenos para iniciar la obra y al cabo de 6 años, en 1989, la imagen fue trasladada allí. Al mismo tiempo, el párroco de la Catedral fue designado como rector del santuario, a cargo de un culto que en ese año ya congregaba a unos cien mil fieles para los festejos de septiembre (Costilla 2013).

En la presentación de estas tres historias, el recorte temporal ha seguido dos criterios. En primer lugar, la aceptación generalizada de cada imagen como símbolo sagrado. En este proceso, como veremos en el cuarto apartado, ha sido clave el papel del milagro, interpretado desde la perspectiva nativa como una demostración del poder y la sacralidad de las imágenes. El segundo criterio para el recorte ha sido el reconocimiento del templo como santuario. Ya fuera en términos nativos o desde una mirada analítica, he considerado como elemento central a los peregrinos: la presencia de estos fieles visitantes demuestra que la capilla o iglesia donde reside la imagen-símbolo puede ser considerada un santuario.

Es decir, que parto de entender las imágenes de culto como símbolos religiosos y sus templos como santuarios. Ambas categorías analíticas fueron clave para interpretar los hechos 


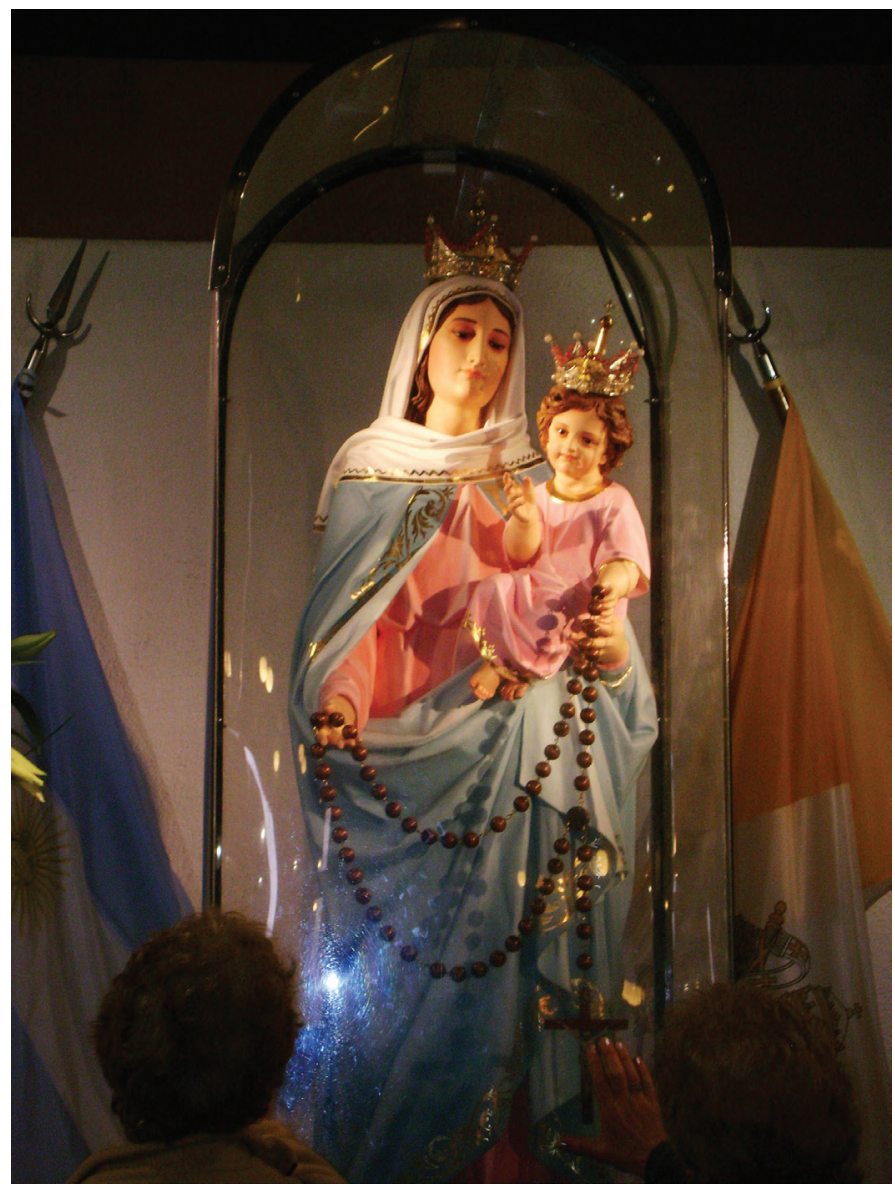

Figura 3. Virgen de San Nicolás en su santuario

(fotografía de la autora, 15/10/2010)

reconstruidos a partir de las fuentes. Pero mientras en los tres casos he registrado la categoría nativa de santuario, no sucede lo mismo con el concepto de símbolo religioso, al cual entiendo casi exclusivamente desde una perspectiva teórica. Si tomamos los símbolos como entidades polisémicas y polémicas en su interpretación (Ricoeur 1976; Turner 1980; Eliade 1994; Costilla 2014), y a los religiosos como parte de un sistema cultural (Geertz 1987; Carvalho 2000), podemos afirmar que las imágenes de culto actúan siempre como símbolos religiosos para quienes participan de ese culto. A su vez, tales símbolos existen como materialidades conectadas con lo sagrado, por las potencias que expresan, pero sobre todo porque han sido investidos de ese poder: desde perspectivas nativas, las imágenes materiales son tanto vehículos como objeto de devoción, representando y presentando lo sagrado (Ceriani Cernadas 2007; Menezez 2011; Meyer et al. 2011; Bovisio y Penhos 2016). Así, cualquier símbolo sagrado supone prácticas de sacralización de determinadas entidades (Martín 2007), las que constituyeron a esos símbolos y las que los actualizan y recrean permanentemente.

Respecto a los santuarios, son templos donde una imagen o reliquia recibe una especial devoción, caracterizados por la atracción de peregrinos y por el significado milagroso del objeto de culto que albergan (Díez Taboada 1989; Christian 1991; Calavia Saez 2002; Steil 2002; Rubial 2008; Rodríguez Becerra 2016). El "área de devoción” de un santuario puede ser local, 
regional, nacional o internacional, según el alcance de la difusión que haya tenido ese objeto de culto por parte de sus cuidadores o gestores (Rodriguez Becerra 2016). En cualquier escala, sin embargo, al ser poderosos sitios sagrados (Eliade 1994; Steil 2002; Schwarz 2008; Acosta Luna 2011), irradiadores y congregadores, se vuelven centros relevantes para las ciudades y localidades donde se ubican -reconocibles éstas como hierópolis- (cfr. Díez Taboada 1989; Carballo 2009-10; Ferro Medina 2010; Flores 2013). En cada santuario, por lo tanto, se destaca al menos un símbolo religioso en tanto símbolo dominante (Turner 1980) -una virgen, un santo, un cristo o una reliquia- y en todos los casos fueron fundantes los milagros, entendidos como signos de Dios (desde una perspectiva teológica) y/o como acontecimientos que superan las expectativas de los fieles (perspectiva devocional) (Lorandi y Schaposchnik 1990; Calavia Saez 2002; Costilla 2014:46-47). También es un hecho que cada uno de estos templos posee fechas sagradas y su festividad anual principal, pero por razones de espacio no serán objeto de análisis en este artículo.

Con este marco teórico-conceptual, el variado corpus de fuentes fue trabajado siguiendo la perspectiva de la hermenéutica de la revelación y la sospecha (Ricoeur 1983; Gadamer 1997; Wright 2015), combinando la "escucha" atenta sobre aquello que "revelan" los símbolos, desde las explicaciones nativas, con una mirada crítica que permita desentrañar los procesos que constituyeron a esos símbolos como tales. Para el caso de los relatos sobre "milagros" -ligados a la tradición narrativa de una "literatura hierofánica" (Rubial 2008)-, los retomé de acuerdo al criterio de verdad nativo (Costilla 2008:43-44; Rubial 2008; Segato 2016): más allá de la veracidad histórica, lo narrado interesa por sus significados y efectos en determinado contexto (Todorov 2008). En este sentido, tales relatos dan cuenta de la existencia de personas y grupos que interpretaron culturalmente determinados episodios como acontecimientos (Sahlins 1988), bajo categorías religiosas -milagro, gracia, favor, aparición o signo-que son a su vez categorías culturales (Geertz 1987).

De esta manera, retomaré a continuación los tres procesos históricos presentados en este apartado para concentrarme en los hechos fundantes de cada santuario. Tomaré como eje al símbolo religioso y reconstruiré cómo cada imagen de culto fue producida y consagrada como símbolo dominante de un santuario católico. Como señalé en la introducción, para sistematizar el análisis comparativo distinguí tres aspectos en esos procesos: la producción de la imagen de culto, el surgimiento de la devoción y los relatos sobre milagros. En cada uno de ellos recorreré de forma sintética los hechos registrados dentro de cada caso para luego analizarlos comparativamente y examinar posibles regularidades.

\section{CREADORES DE SACRALIDAD: PRODUCCIÓN -MATERIAL Y SIMBÓLICA- DE LA IMAGEN DE CULTO}

Sobre el caso de la Virgen de Copacabana, se trata de una imagen elaborada prácticamente en el momento en que se origina la devoción, bajo las motivaciones de una familia de origen incaico, integrada en la parcialidad local anansaya ${ }^{3}$ con relativos privilegios dentro de la sociedad colonial y apoyada por el cura del pueblo. La elección de la Virgen de la Candelaria ha sido explicada desde su conexión con el calendario agrícola local -por coincidir su festejo el día 2 de febrero con la época de cosechas- y por la presencia regional de la advocación debido a la acción previa de los dominicos (Costilla 2010, 2014). Por otra parte, según el relato del propio escultor Francisco Tito Yupanqui, transcrito en la crónica del agustino Ramos Gavilán, la producción de su obra fue un proceso itinerante y de bastantes intervenciones: mientras que en sus primeros ensayos colaboraron sus hermanos (uno de ellos curaca), su escultura definitiva la comenzó en Potosí con un maestro español y antes de regresar a Copacabana terminó de perfeccionarla en el convento franciscano de La Paz (Yupanqui en Ramos Gavilán [1621]1976:124-126). 
El mural del Señor de los Milagros, en cambio, es una imagen de autor anónimo, solo reconocido por su origen africano, ${ }^{4}$ por residir en el barrio colonial limeño conocido como Pachacamilla y por participar allí de una cofradía de negros. En ésta habría surgido la iniciativa de pintar la imagen: un Cristo Crucificado junto a su Madre y la Magdalena, ${ }^{5}$ bajo influencias del cura local y de los jesuitas que evangelizaban en la ciudad (Colmenares 1771:6; Sánchez Rodríguez 2002; Costilla 2015). Las fuentes indican que una vez oficializado el culto en 1671, el Virrey dispuso que agregaran en el mural a las imágenes del Espíritu Santo y el Padre Eterno (Vásquez de Novoa [1766]1868:4; Antuñano 1689 en Banchero Castellano 1972). Así, al quedar representada la santísima trinidad, la imagen fue potenciada como símbolo y como vehículo para la evangelización.

La imagen de la Virgen del Rosario de San Nicolás es la que más difiere en este punto porque se desconoce a su creador material: se trata de una talla de madera elaborada en Roma y enviada a la iglesia parroquial nicoleña en el año 1884 (El Norte 1984). En ese entonces, la virgen había sido pedida por el cura local y donada por una vecina (El Norte 1986; Bruno 1994; Laurentin 2006:22; Costilla 2014:247). Es decir, que cuando comenzó el culto, en 1983, la virgen llevaba ya un siglo en la ciudad. Por ende, cobra relevancia la mujer que experimentó las visiones luego asociadas a esta imagen: Gladys, una feligresa que vivía a $50 \mathrm{~m}$ del actual Santuario. Al menos en términos simbólicos, la "vidente" puede ser entendida como una segunda "productora" de la Virgen del Rosario de San Nicolás, en tanto le dio forma -una apariencia y un mensaje concretos- al objeto de culto. Su visión, de "una mujer con una túnica rosa y un manto celeste, con un niño sentado en el antebrazo izquierdo", fue la figura que las autoridades eclesiásticas asimilaron luego con la escultura italiana (Bruno 1994:51-55). De esta manera, tanto la vidente como los sacerdotes locales han sido los verdaderos creadores de esta imagen de culto.

Comparando estos tres procesos hemos realizado un primer análisis respecto al contexto temporal. Las imágenes de Copacabana y Lima, creadas en el período colonial, respondían al proyecto evangelizador de la Corona española sobre la población indígena y afrodescendiente. A diferencia de éstas, la producción material de la imagen nicoleña, a manos de un escultor italiano, corresponde al contexto de romanización de la Iglesia católica latinoamericana promovida por el Vaticano en la segunda mitad del XIX -pasadas varias décadas desde la disolución del Patronato Regio y en pleno proceso de secularización y reacomodamiento de las relaciones entre Iglesia y Estado (cfr. Di Stéfano y Zanatta 2000; Roux 2014)-.

Consideramos que tales circunstancias contextuales explican las principales diferencias en la creación de las imágenes de culto. Los casos de Copacabana y Lima involucraron imágenes elaboradas especialmente y el de San Nicolás, una imagen resacralizada a partir de una serie de apariciones. Mientras los dos primeros se centraron en los productores materiales de las imágenes, arraigadas éstas en tradiciones prehispánicas (catolicismo andino y catolicismo de raíces africanas y posiblemente indígenas), el tercero focalizó en una producción simbólica, en el llamado "Acontecimiento Mariano", donde se propagó un catolicismo de carácter más ecuménico. Esto, como veremos a continuación, tendrá implicancias en cuanto al carácter de las devociones surgidas.

Sobre el análisis de quienes produjeron las imágenes, se destaca el caso de Yupanqui por haberse vuelto un escultor reconocido por las autoridades coloniales y valorado por sus obras milagrosas (Lizárraga [1605]1968:70; Calancha [1657]1972:215) ${ }^{6}$. Los cronistas agustinos resaltaron su condición de "indio noble, sangre de los Ingas reyes" (Calancha [1657]1972:185), pero también su "llaneza, bondad y santa simplicidad" (Ramos Gavilán [1621]1976:124). Aunque por su perfil "noble" contrasta con el anónimo pintor del Cristo limeño, podemos equiparar de algún modo a ambos productores-artistas en la medida en que pertenecían a la población colonizada/ evangelizada. Además, así como Yupanqui fue presentado como un pintor sin formación artística y movido por la Virgen (Ramos Gavilán [1621]1976; Calancha [1657]1972: 190; cfr. Wachtel 2001), el negro que pintó al Señor de los Milagros ha sido descripto como "rudo" y "ageno de toda instrucción en el arte de pintar, dirigida su mano de superior impulso" (Vásquez de Novoa 
[1766]1868:3; Colmenares 1771:XXX). Es decir que en ambos casos se trató de producciones neófitas inspiradas por las divinidades.

Estos rasgos se inscriben dentro de los patrones narrativos más extendidos sobre el origen de cultos y santuarios dentro del catolicismo (Velasco Maillo 1989; Christian 1990, 1991; Estenssoro Fuchs 2003; Fogelman 2003, 2006; Rubial 2008; Rodríguez Becerra 2016, entre otros). Las descripciones sobre quienes produjeron las imágenes -ya sea manualmente o por hallazgos/ apariciones milagrosas-suelen subrayar su humildad y sus dificultades iniciales para lograr aceptación. También es frecuente que los relatos destaquen el hecho de haber sido guiados por el propio ser sagrado cuya imagen elaboraron. Se entiende que la sencillez y falta de recursos, combinada con una inspiración divina, contribuyen a afianzar las imágenes entre sus potenciales devotos.

Con sus distancias, el caso de la Virgen del Rosario no difiere demasiado en este punto. Aunque el autor material de la imagen es desconocido, las fuentes señalan a la "vidente" Gladys y recalcan su sencillez y humildad: un ama de casa de una familia "de trabajo" (Laurentin 2006; Pérez 2007). Ha sido caracterizada desde su "piedad normal" y su falta de formación teológica o bíblica -con una también escasa formación escolar-. Al mismo tiempo también se la define como equilibrada e inteligente, como mujer "normal, sólida, realista" (Bruno 1994:27; Laurentin 2006:13-15; Pérez 2007:95 y ss.), cualidades relevantes en este caso por los cuestionamientos que las revelaciones privadas suelen generar en torno a su autenticidad. Debido a ese rol de "vidente" y "mensajera" de la Virgen -en un sentido más cercano al caso de Yupanqui- la mujer recibió también un cierto halo de sacralidad: mientras ella mantuvo siempre un total hermetismo y discreción, los peregrinos dejan objetos religiosos y cartas en la entrada de su casa.

En la comparación sobre el papel de los productores, consideramos también el lugar en donde crearon sus imágenes. Y en este aspecto, se distinguen los casos de Copacabana y San Nicolás frente al de Lima, porque involucraron-desde circunstancias distintas-localidades externas a la del santuario: la primera imagen tallada entre Potosí y La Paz, siguiendo trajines del escultor andino y sus parientes, y la segunda elaborada en Roma. Al indagar sobre las implicancias de esto, en el primer caso hemos registrado devociones surgidas en esas ciudades natales de la imagen (Calancha [1657]1972:279; Costilla 2014), lo cual nos induce a pensar en una red devocional tejida por la movilidad del artista nativo y su obra. Mientras que en San Nicolás el origen romano señala una vinculación directa con los circuitos de la jerarquía eclesiástica, independientemente de quién haya sido el artista. Frente a esto reforzamos el papel de Gladys como verdadera creadora de la imagen de culto: más allá de la realización material de la escultura, fueron los detalles de sus visiones los que habrían dado origen a la imagen-símbolo. De hecho, los devotos celebran el "cumpleaños de la Virgen" en el aniversario del primer día de las visiones de Gladys (25 de septiembre de 1983); cabe interpretar entonces que la "ciudad natal" de esta Virgen del Rosario no es Roma sino San Nicolás. Pasamos entonces a profundizar en cómo se conectaron las creaciones con sus devotos.

\section{¿DE LA IMAGEN A LA DEVOCIÓN O DE LA DEVOCIÓN A LA IMAGEN?}

En los dos santuarios coloniales encontramos que la elaboración de las imágenes fue prácticamente simultánea al surgimiento de las devociones. En el caso de la Virgen de la Candelaria de Copacabana, podemos señalar como inicio al 2 de febrero de 1583: ese día, aquélla fue llevada hasta la iglesia del pueblo en solemne procesión y se fundó su cofradía, ${ }^{7}$ ambos eventos con participación del corregidor y de sacerdotes jesuitas (Ramos Gavilán [1621]1976:123).

Las fuentes describen además cuáles fueron las motivaciones previas: durante un período de heladas y mal tiempo, las autoridades nativas, aconsejadas por el cura, decidieron fundar una cofradía para encomendar sus cosechas a algún santo intercesor. Pero su elección fue causa de debate en la población local: especialmente entre las parcialidades anansaya y urinsaya. Es decir 


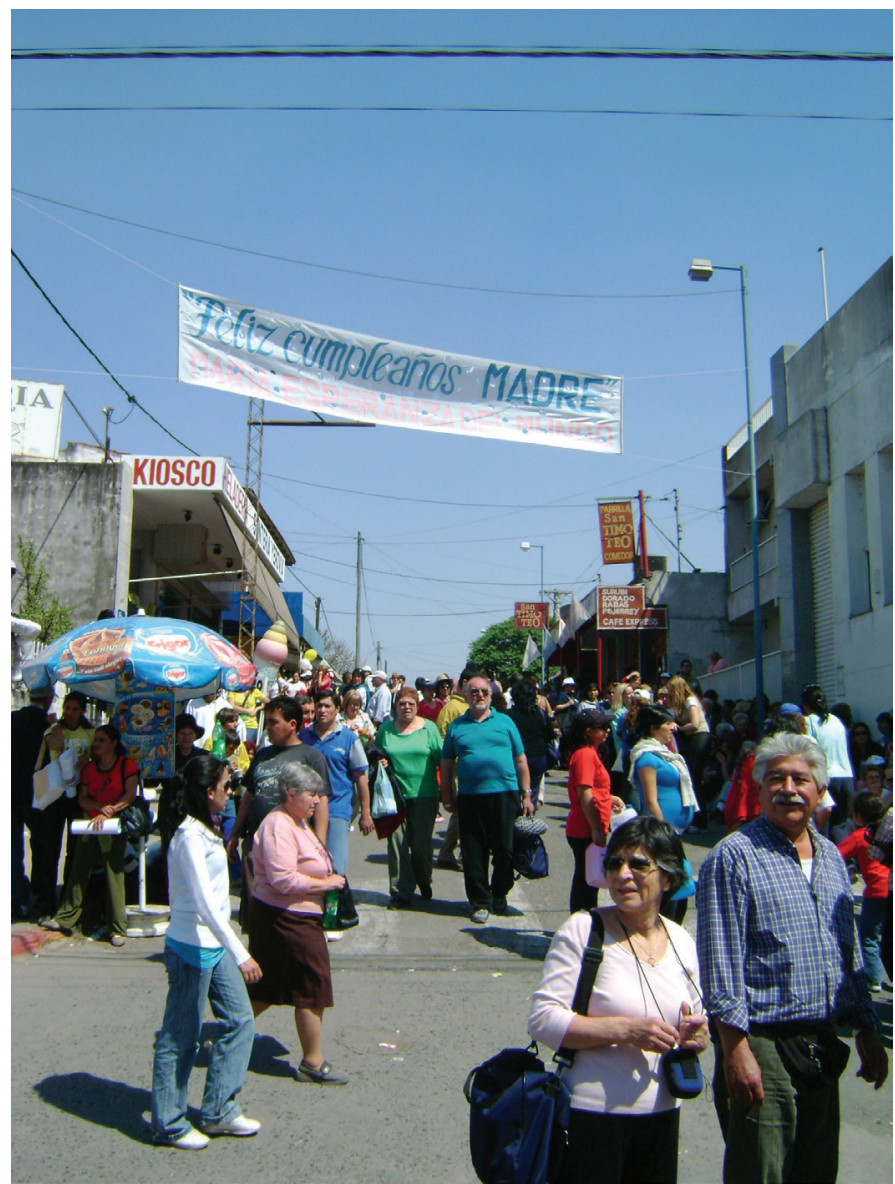

Figura 4. Calle adyacente al santuario en el $25^{\circ}$ aniversario de la Virgen (fotografía de la autora, 25/09/2008)

que la necesidad de un objeto de devoción católico fue previa a la decisión por la Candelaria, impulsada ésta desde la parcialidad del escultor (anansaya). Además, los esfuerzos de la familia de Yupanqui para que su virgen fuera aprobada indican que la devoción surgió en una articulación entre intereses coloniales e indígenas. La imagen católica podía reemplazar devociones prehispánicas arraigadas en el Lago Titicaca (aunque en la práctica la virgen terminara movilizándolas, asociada a sacralidades locales como wakas y apus); pero al mismo tiempo, al representar a Yupanqui y sus parientes, pudo significar mayor prestigio para ellos (Salles-Reese 1997; Costilla 2010, 2014; Bovisio y Penhos 2016).

Sobre la devoción al Señor de los Milagros, aunque los registros iniciales son menos descriptivos, he identificado dos orígenes sucesivos: hacia 1650, cuando un grupo de afrolimeños pintaron al Cristo en un mural y comenzaron a venerarlo, y en 1670, cuando un vecino español de ese mismo barrio de Pachacamilla reavivó la devoción entre los feligreses (Liñán y Cisneros 1682). En 1650 fue decisivo el accionar evangelizador de los jesuitas, quienes promovieron la devoción a Jesucristo entre los negros e indígenas de la ciudad. Al mismo tiempo, más allá de las prácticas particulares de los cofrades de Pachacamilla, fue un momento donde otras ciudades coloniales también entronizaron cristos que resistían sismos (Costilla 2015). El mural limeño, como ilustraremos en el siguiente apartado, no tardó en demostrar su potencia quedando intacto 
durante un terremoto en 1655; pero el derrumbe de la ermita llevó a los cofrades a abandonarlo.

El resurgimiento de esta devoción llegó por un vecino español, Andrés de León, quien arregló el templo en 1670 y fomentó su culto entre los feligreses de las parroquias del barrio. Las fuentes indican que los devotos -en su mayoría de origen africano- se reunían junto a la imagen cada viernes a la noche para entonar salmos y lamentaciones acompañados de bailes y de un "culto menos decoroso", donde las autoridades percibieron un cierto "desorden de las jentes de ambos secsos que ya pasaba, con pretesto de devocion a escándalo" (Vásquez de Novoa [1766]1868:5; Colmenares 1771:7). Estas prácticas levantaron sospechas entre los párrocos y motivaron en el Arzobispo y el Virrey la resolución de eliminar la imagen. Pero durante el mismo instante en que iban a borrarla, una manifestación pública del Cristo revirtió esa decisión y movilizó definitivamente la devoción de autoridades y sociedad local, evidenciada ésta durante la primera misa que se ofició frente a la imagen el 14 de septiembre ${ }^{8}$ de 1671.

La mayor diferencia que podemos marcar entre estos dos cultos y la devoción por la Virgen del Rosario es que en tiempos coloniales toda la sociedad era considerada parte de la cristiandad. Tanto en las ciudades como en los pueblos de reducción, las personas podían ser más o menos devotas de ciertas imágenes, pero siempre pertenecían a una parroquia que de algún modo imponía los marcos y referentes de la vida religiosa (Di Stéfano y Zanatta 2000; Díaz Araya et al. 2012). El imaginario colonial no distinguía entre feligreses y ciudadanos, y en sus representaciones más hegemónicas la única adscripción sociorreligiosa válida era la cristiano-católica. Ésta se imponía sobre heterogéneas y maleables prácticas y creencias, y en franca oposición a las distintas calificaciones condenatorias -idólatras, herejes, etc. (cfr. Bernand y Gruzinski 1992).

Si bien este complejo entramado sociorreligioso mostraba tradiciones culturales y sagradas plurales -de raíces europeas, americanas y africanas-, podemos, hasta cierto punto, contrastarlo con el pluralismo religioso que comenzó a reconocerse en las sociedades latinoamericanas desde la segunda mitad del siglo XX, en especial desde los años 1980 (Parker 2014; Rodríguez López 2021). Considerando esto, el contexto que dio lugar al culto de San Nicolás presenta una complejidad religioso-espiritual y un dinamismo identitario diferentes (cfr. Frigerio 2007; Parker 2014) -con un particular escenario también en lo político y económico (Rivero 2008; Flores 2013). Podemos señalar entonces una distancia radical entre este caso y los coloniales en cuanto a las condiciones de adhesión de los creyentes a las imágenes sacralizadas y las motivaciones para acercarse a venerarlas. Si en Copacabana y Lima fue decisiva la política evangelizadora de la Corona española, en San Nicolás, como veremos a continuación, hubo otros factores de peso.

A esto se suma que la devoción por la Virgen de San Nicolás surgió con un siglo de desfasaje respecto del momento de creación de la imagen. Cuando esta escultura fue enviada desde Roma, en 1884, los feligreses nicoleños no consolidaron un culto en torno a ella. Pero cuando en 1983 el párroco de la Catedral determinó que las apariciones relatadas por una vecina coincidían con esa antigua imagen guardada en el campanario, los fieles no tardaron en acercarse a rezarle. ¿Qué motivaciones pudieron operar en este contexto? Como explicamos en otro trabajo, un hecho que debió incidir en el desarrollo inicial de la devoción -en términos espirituales e institucionales- fue una crisis socioeconómica local, ligada a la privatización de una industria vital para San Nicolás 9 (Rivero 2008; Flores 2013; Costilla 2021). Y en buena medida gracias a la difusión masiva que tuvo el fenómeno de las apariciones, a través de distintos medios, la devoción logró extenderse de manera exponencial entre fieles locales y peregrinos.

Aunque se trataba de revelaciones privadas, que la Iglesia no puede imponer como dogma de fe, el culto recibió una fuerte legitimación diocesana (Laurentín 2006). Las autoridades episcopales -acompañadas por el Municipio (cfr. Flores 2013)- lo encarrillaron rápidamente: entronizaron una imagen preexistente, conformaron una comisión para evaluar a la "vidente", gestionaron la construcción de un santuario y designaron al párroco como rector. Pero al mismo tiempo subrayaron la devoción popular: cuando la imagen fue trasladada definitivamente a su nuevo templo, 
en 1989, el Obispo señalaba "el pueblo que aquí peregrina [...] es el único animador de este acontecimiento", "estas paredes han sido levantadas por el pueblo y las coronará exclusivamente el pueblo" (Castagna en Bruno 1994:142). Así, se destacaba el lugar del "pueblo" devoto como único padrino y promotor del culto.

Es decir, en los tres casos observamos movilizaciones de los cultos "desde abajo", ligadas a la posición social de los productores de las imágenes, y encauzamientos "desde arriba", donde los agentes eclesiásticos moldearon las devociones de acuerdo al dogma y la liturgia católica, pero sin dejar de enfatizar el protagonismo de los fieles. Por otra parte, pudimos ver que es prácticamente imposible considerar estos procesos de creación de devociones por fuera de los episodios milagrosos adjudicados a las imágenes en cuestión. A ellos nos dedicamos en el siguiente apartado.

\section{LOS CIMIENTOS MILAGROSOS}

En palabras de un sacerdote de San Nicolás, los milagros "son hechos contundentes, que no tienen explicación científica, humana, están hablando de que Dios está interviniendo ahí directamente" (Entrevistado A 2008) ${ }^{10}$. En el contexto de evangelización colonial, ese poder revelador del milagro en tanto signo de Dios (Lorandi y Schaposchnik 1990), fue explotado por parte de los agentes eclesiásticos para que indios y negros incorporaran la simbología cristiana (Marzal 1999; Wachtel 2001; Costilla 2014). Pero más allá de ese rol cristianizador, de conversión espiritual, en los tres casos se hizo evidente también que los milagros fueron sucesos decisivos en el afianzamiento de determinadas imágenes como objetos de culto.

Nos detendremos, entonces, en los milagros que he llamado fundantes, aquellos adjudicados a estas imágenes durante sus procesos de consolidación. Se analizarán comparativamente siguiendo una tipología general presentada en un trabajo previo (Costilla 2010), donde hemos distinguido entre milagros individuales, impersonales y colectivos según a quiénes se indica que están dirigidos. Al mismo tiempo, se trata de episodios que fueron publicados y difundidos, es decir que, cuando no fueron atestiguados públicamente, trascendieron los ámbitos privados o personales (Christian 1990) y pudieron ser interpretados y apropiados por distintos actores de los cultos (Costilla 2014, 2021).

En el caso de Copacabana las fuentes de la época destacaron cuatro milagros. El primero se produjo en el Convento de San Francisco de La Paz en 1582, cuando Yupanqui terminaba allí a su imagen: el fraile que la tenía en su habitación fue deslumbrado por unos rayos que salían de la escultura. El suceso actuó como disparador del culto porque movilizó al corregidor y al cura de Copacabana, así como al curaca de los urinsayas (quienes no aceptaban una virgen de factura local), para decidir trasladar la imagen al pueblo. El segundo prodigio fue durante la procesión del 2 de febrero de 1583, evento que ya señalamos como inicio oficial del culto: una cruz de bronce cayó sobre el corregidor y causó admiración entre los presentes porque "con ser pesada la cruz no le hizo daño alguno”. Según el cronista Ramos Gavilán ([1621]1976:124), a partir de ese milagro "empezaron los fieles a venerar la Santa Imagen". Al parecer, fue necesaria una revelación pública de los poderes de la Virgen, manifestados inicialmente en la privacidad de la celda de un religioso.

Pero hubo dos prodigios más que terminaron de consolidar la aceptación de esta imagen. Uno fue su autotransformación al poco tiempo de ser entronizada: cuando en 1583 decidieron retocarla para que la corona del Niño Jesús no tapara el rostro de la Virgen, aquél apareció cambiado de posición. El milagro a simple vista impersonal, fue empleado por el cura para exhortar a los nativos a venerar la imagen, en tanto podían interpretarlo como un favor hacia ellos (Ramos Gavilán [1621]1976:129; Calancha [1657]1972): la Virgen y su Hijo estaban legitimando la imagen de Copacabana y, por ende, la capacidad indígena de producir sacralidad. El siguiente milagro 
decisivo también tuvo a nativos como beneficiarios. Durante la siembra del año 1587, una serie de lluvias inesperadas movilizaron la definitiva aprobación por parte de la parcialidad urinsaya: al ver que el aguacero caía solo sobre las tierras de los anansayas, quienes invocaban a la Virgen, los urinsayas se vieron persuadidos a rezarle y luego de eso llovió sobre sus chacras (Ramos Gavilán [1621]1976:131; Calancha [1657]1972). Ambos sucesos demuestran entonces que, aun con la devoción consolidada, parte de la población nativa permanecía incrédula ante la imagen.

Sobre el Señor de los Milagros hemos identificado tres hechos prodigiosos fundantes. El primero fue el "especial milagro" de conservación de la imagen a pesar de ser un "tosco" y endeble muro de adobes. Durante el terremoto de 1655 quedó "indemne", pero el hecho no fue disparador del culto en ese momento. Recién en 1670, un feligrés español-A. de León- reavivó la devoción luego de admirar la permanencia del mural tras 15 años de estar expuesto (Vásquez de Novoa [1766]1868:4-6; Antuñano 1689 en Banchero Castellano 1972:65). Fue entonces cuando sucedió el segundo prodigio, la desaparición de un tumor que aquél padecía. Al ser interpretado como favor del Cristo hacia quien se ocupó de venerarlo (Colmenares 1771:7), el milagro de sanación atrajo más devotos. Así, el tercer prodigio corresponde a los sucesos -ya señalados- que evitaron la eliminación de la imagen ordenada por las autoridades en 1671. Quienes asistieron a la tarea, presenciaron una serie de manifestaciones que interpretaron como "maravillas": el desmayo del primer indio que intentó borrarla, la inmovilización del brazo del segundo, un embellecimiento de la imagen y un aguacero repentino. Los presentes certificaron que era "clara la voluntad de N. Sr. que no se borrase su sacratísima imagen” (Vásquez de Novoa [1766]1868:5-6) y esto motivó la definitiva aceptación oficial del Cristo.

Para el culto de San Nicolás, podemos afirmar que hubo un milagro dominante-las apariciones y mensajes marianos-, precedido y acompañado por otros fenómenos prodigiosos. El primer suceso registrado fueron unos rosarios refulgentes, en la casa de una vecina de la futura "vidente" y luego en la casa de ésta. En ambas ocasiones se acercaron fieles interesados en "observar el 'milagro'" (testimonios en Bruno 1994:33; Entrevistada B 2010-2012) ${ }^{11}$. Al día siguiente comenzaron las apariciones experimentadas por Gladys: las primeras solo visiones y luego mensajes de la Virgen (Bruno 1994). ${ }^{12}$ Estas experiencias pueden analizarse desde una categoría específica de apariciones, habitual en el siglo XX: una figura divina que se presenta "en carne y hueso", que puede hablarle a el/la vidente y mostrarle o entregarle objetos (Christian 1990).

Si bien las apariciones y mensajes son considerados milagros en sí mismos, al ser revelaciones privadas se volvieron necesarios otro tipo de milagros más visibles: los "signos". Éstos fueron fundamentales para que la Iglesia avalara el contenido de los mensajes marianos (Entrevistado A 2008, ver nota 10). Sumados al suceso inicial de los rosarios, las fuentes señalan cuatro signos: a) un rayo de luz que cayó sobre el "campito" donde luego se construyó el santuario; (b) una fuente de agua considerada milagrosa (conocida como el "agua de María"); (c) una serie de estigmas que comenzó a recibir la vidente; y (d) una primera curación adjudicada a la imagen. Con excepción de este último de sanación, considero que los episodios anteriores pueden incluirse bajo la categoría analítica de signo (Christian 1990), en tanto dejan una huella sensible y pueden ser percibidos por distintas personas.

Si comparamos las tres historias, podemos notar ciertas regularidades en el tipo de milagros fundantes. En primer lugar, al trabajar con relatos oficiales -o inspirados por los fieles, pero oficializados-, todos los prodigios registrados correspondieron a interpretaciones teológicas. Aunque los agentes eclesiásticos, especialmente en la actualidad, son prudentes frente al uso del término milagro cuando caracterizan ciertos acontecimientos como extraordinarios o como "signos", "gracias", "favores" o manifestaciones divinas, podemos analizar a tales sucesos bajo la misma categoría de milagro.

En segundo lugar, propongo una clasificación tentativa entre milagros disparadores, reforzadores y de consolidación/extensión (los cuales, a su vez, pueden corresponder a sucesos únicos o 
en serie). Es decir, el prodigio fundante por excelencia vendría a ser el "disparador" del culto, y en los tres casos además fueron de tipo impersonal (esto es, sin beneficiarios directos): los rayos de luz de la Virgen de Copacabana, la conservación del Cristo limeño y las apariciones de la Virgen de San Nicolás. Es probable que eso haya implicado una cierta apertura social de los cultos, en tanto las imágenes no surgieron en principio como favorecedoras de un grupo o individuo particular. Por otra parte, con el ejemplo de Lima notamos que el impacto del milagro disparador fue relativo en un primer momento, hasta que el feligrés A. de León revalorizó el suceso -pasados 16 años- y organizó definitivamente la devoción.

En cuanto a los reforzadores, el de Lima-la sanación de A. de León-parece ser el de mayor peso debido a ese impacto relativo que había tenido el prodigio disparador. Se trataba además de un milagro individual, que favorecía a un español en el contexto de una devoción que había nacido asociada a los negros. En el caso de Copacabana observamos una lógica similar: un milagro individual que benefició al corregidor -salió ileso tras caerle encima una cruz- en el contexto de una devoción vinculada a los indios. Como retomaré en las conclusiones, considero que la similitud puede explicarse por el contexto de la evangelización colonial. Respecto al milagro de San Nicolás, comparte con aquellos el haber contribuido a apuntalar una devoción, pero se distingue por haber sido un hecho impersonal (la caída de un rayo de luz) y por aquello que interpretaron sobre él en tanto signo: no demostraba tanto los poderes de una imagen, sino la "autenticidad" del fenómeno de las apariciones.

Los milagros de consolidación/extensión, por su parte, fueron impersonales en los tres casos, pero el de Copacabana (las lluvias inesperadas) tuvo una particularidad: en términos nativos fue interpretado como milagro colectivo, por beneficiar a la población indígena. El de Lima (los sucesos que impidieron eliminar la imagen) promovió la oficialización del Cristo como objeto de culto, con una extendida aceptación dentro la sociedad limeña. El de San Nicolás, por su parte, fue un nuevo signo similar al anterior, pero con un correlato material (el "agua" de María), de potencialidades curativas, por lo cual colaboró en la afirmación y extensión del culto especialmente entre fieles y peregrinos.

Una vez consolidadas estas devociones, otra cuestión común a los tres santuarios es la instancia en la cual las imágenes materiales fueron sacralizadas y se transformaron en verdaderos símbolos religiosos: esto es, cuando la talla de la Candelaria de Yupanqui, el mural de Pachacamilla y la escultura italiana de María del Rosario pasaron a ser la Virgen de Copacabana, el Señor de los Milagros y la Virgen del Rosario de San Nicolás. Considero que en esas instancias es cuando la frontera entre imagen y realidad sagrada se va borrando, cuando las esculturas y pinturas reciben la potencia de aquellos a quienes están representando (Jesucristo o su madre María). Aunque estas imágenes-símbolos sean una imitación o figuración (simulacro) de la presencia sagrada (el referente o prototipo), una re-presentación de lo divino (lo ausente/invisible), la experiencia humana -devocional en este caso- las vive como reales (Freedberg 1992; Fogelman 2006; Menezez 2011; Bovisio y Penhos 2016).

En este sentido, sostengo que una prueba fehaciente de la consolidación de las devociones son las réplicas de las imágenes sagradas. Ya sea para sacarlas en procesión o para reproducir el culto en otras iglesias, el propio acto de producir una réplica implica que la imagen original ya ha sido sacralizada como objeto de culto católico. Las réplicas siempre son una reproducción material de la imagen sagrada e implican una nueva sacralización, aun desde reproducciones mecánicas y masivas -incluso las estampitas conservan su aura, en sus vulnerables soportes y su producción/circulación marginal (Menezez 2011)-. Considero, entonces, que la tensión propia de las imágenes sagradas entre su materialidad iconográfica (formas, colores, etc.) y la trascendencia del personaje que están representando se expresa doblemente en estas copias: cada nueva imagen-objeto es creada como representación de la re-presentación y percibida como la misma potencia en acción (Gruzinski 1995; Menezez 2011). Así, en una paradójica dialéctica, las imá- 
genes sagradas son al mismo tiempo únicas y trascendentes, pero repetibles a voluntad (Eliade 1994; Costilla 2014:36,335).

Por último, si uno avanza en milagros posteriores, podría decirse "por fuera" de cada relato fundante, es posible observar que la apertura de los cultos a múltiples apropiaciones y derivaciones volvió prácticamente infinito el campo de acción de las imágenes. Aunque estos milagros post-consolidación, tal como los he definido (Costilla 2014:364), quedarán para un futuro trabajo, cabe señalar un rasgo que los distingue, en tanto permite reforzar la hipótesis de una regularidad en estos procesos. Mientras en la etapa fundante los prodigios suelen ser publicados y difundidos, lo cual es esperable si se busca consolidar una devoción, cuando la imagen ya ha sido convertida en objeto de culto los milagros se multiplican junto con los devotos, pero quedan más restringidos al ámbito privado. Se hacen visibles, sin embargo, en los exvotos, ${ }^{13}$ en los registros especiales que suelen habilitar los administradores del culto y en las nuevas producciones narrativas sobre la historia de las imágenes y sus santuarios. ${ }^{14}$

Respecto a esas nuevas narrativas, son notables las relecturas sobre los relatos fundantes, siempre asentados entre hechos históricos y legendarios. En los tres santuarios hemos registrado que fuentes posteriores reinterpretaron las narrativas tradicionales e incluso que aportaron nuevos datos referidos tanto a los creadores de las imágenes como a los orígenes de la devoción y a los primeros milagros. Destaco dos ejemplos relativos a los cultos coloniales. Sobre la Virgen de Copacabana, cronistas posteriores describieron un milagro-aparición frente al escultor Yupanqui durante el momento en que realizaba su obra, en Potosí. ${ }^{15}$ En cuanto al Señor de los Milagros, desde los años 1960 distintas publicaciones comenzaron a darle una imagen más definida y protagónica al pintor de la imagen: en un contexto de creciente reconocimiento a la presencia afrodescendiente en el culto, las fuentes lo presentan como esclavo y/o con nombre y apellido (El Comercio 1968; Banchero Castellano 1972:66, 236 ). Las historias analizadas en este trabajo, como sucede con cualquier relato fundacional (cfr. Candau 2008), han sido modificadas por los actores del culto -tanto especialistas como creyentes (Bourdieu 2009)- quienes las reprodujeron y transmitieron de generación en generación.

\section{CONCLUSIONES}

Luego de analizar el trasfondo histórico de tres cultos latinoamericanos de manera comparativa, es posible examinar algunos rasgos y regularidades sobre el surgimiento y la consolidación de santuarios católicos e imágenes milagrosas. Frente a la pregunta sobre si es posible reconocer lógicas comunes en tales procesos, propongo una respuesta afirmativa. Pero ante las evidencias presentadas, también es posible comenzar a deslindar esas lógicas en distintos niveles, entre una más católica universal, relativa a dinámicas propias de la construcción de este tipo de santuarios y otras derivadas de factores contextuales: principalmente, dentro de dos escenarios americanos distintos, el de la evangelización colonial y el de una diócesis ya secularizada y "romanizada" a fines del siglo XX.

A nivel general, destaco cuatro aspectos que pueden considerarse cercanos a la lógica católica más ecuménica:

1. Cada santuario posee su relato fundante, el cual pudo haber sido registrado con más o menos detalle, por escrito o mediante tradición oral. En estos casos, las fuentes dieron cuenta de un creador (o creadores) de la imagen de culto y de cómo surgió la devoción hacia ella. Este último hecho, el origen de la devoción -más allá de las circunstancias de producción de la imagenmarca el verdadero surgimiento de un santuario católico: cuando un grupo de personas comienzan a venerar a una determinada entidad, sacralizándola como milagrosa. En estos tres santuarios, además, fue clave el papel que tuvo en cada caso la autoridad religiosa local (cura párroco), cada 
uno con el posterior aval de su obispo y finalmente del Papa; es por eso que estos cultos comparten un carácter oficial. Por otra parte, vimos también que los relatos fundantes, siempre constituidos por elementos históricos y legendarios, han sido -y siguen siendo- objeto de distintas reelaboraciones en la medida en que han acompañado la vigencia de los cultos durante décadas o siglos.

2. Las circunstancias en las que se crea un objeto de culto pueden ser constitutivas de su sacralidad: básicamente, entiendo que esta sacralidad puede estar más asociada al personaje religioso (Jesucristo, la Virgen María u otra persona santificada) o a la imagen material que lo representa. En los relatos disponibles para estos santuarios observamos esas circunstancias porque pudimos identificar en qué época y lugar, bajo qué iniciativas y con qué intervenciones se elaboró cada imagen, más algunos rasgos sobre su autor material. Y al contrastar los casos coloniales con el de San Nicolás, donde observamos una "doble" producción del objeto de culto -la primera material y la segunda simbólica-, pudimos examinar el peso de esas circunstancias.

Cuando son más relevantes las manos que tallaron y pintaron, la potencia sagrada parece derivar de la imagen material y su entorno: la Virgen de Copacabana en tanto escultura de Yupanqui o el Señor de los Milagros como mural (afro)limeño (en ambos casos opacando, de algún modo, a las figuras que representaron: la Virgen de la Candelaria y Jesucristo, respectivamente). Pero ¿sucede lo mismo si los autores materiales son desconocidos, en especial para devotos y peregrinos? Según vimos en el caso nicoleño, es probable que la autoría anónima -o incluso su origen romano- hayan influido en que cobró más fuerza el personaje sagrado: la Virgen María en su advocación del Rosario. Luego esta figura, desde las visiones de Gladys en 1983, comenzó a condensar los significados asociados a las apariciones de San Nicolás.

3. Los milagros fueron episodios decisivos en el proceso de sacralización de cada una de las imágenes, cuando resultaron convertidas en objetos de devoción. Pero al analizar su papel en cada culto, y cómo fueron interpretados, pudimos revelar que no operaron de la misma manera en tanto fenómenos legitimadores: mientras en los casos coloniales los milagros consagraron a las imágenes como poderosas y como objetos de culto autorizados, en San Nicolás contribuyeron principalmente a la "autenticidad" de un fenómeno que ya era en sí mismo de carácter milagroso -las apariciones marianas-. Más allá de esto, podemos afirmar que el milagro siempre operó movilizando la aceptación de una nueva imagen o la revitalización del culto a una ya existente.

Por otro lado, el análisis comparativo permitió identificar la reiteración de una secuencia de milagros a los que he categorizado como fundantes, los cuales pueden distinguirse a su vez en disparadores, reforzadores y de consolidación. Esta clasificación secuencial ha sido cruzada con otra categorización general sobre los milagros en cuanto a su orientación -impersonales, individuales o colectivos-. Observamos entonces que los milagros disparadores fueron impersonales en los tres casos, que los reforzadores apuntalaron distintos aspectos del culto, según su carácter, y que los de consolidación, también impersonales, actuaron como episodios definitivos en el afianzamiento de los santuarios. Esto último, se verifica no solo en la percepción nativa del templo como tal -en términos de santuario-, sino sobre todo en la congregación de peregrinos y en la extensión del reconocimiento a las capacidades milagrosas de la imagen. De este modo, una vez consolidadas las devociones, las imágenes materiales se transformaron en verdaderos símbolos religiosos.

4. La instancia de consagración simbólica de las imágenes milagrosas la hemos asociado, además, a las réplicas que sobre ellas se producen: propongo entonces que éstas pueden ser consideradas como evidencias materiales de esa consagración, como pruebas de una devoción ya instalada y de un santuario consolidado. Asimismo, las réplicas en tanto re-producción de una imagen sacralizada, forman parte del proceso de multiplicación de la acción milagrosa de tales imágenes, cuando se reproducen los devotos y -junto con ellos- los milagros asociados a cada personaje religioso. De esta manera, tanto las réplicas como las demás materialidades que los actores del culto manipulan y difunden (estampitas, medallas, relicarios, etc.), son elementos 
claves dentro del proceso posterior a la consolidación de una imagen como símbolo religioso.

Respecto a las lógicas que podemos vincular con contextos latinoamericanos, señalo tres conclusiones principales.

5. En el escenario colonial, los santuarios de Copacabana y Lima mostraron que resultó propicio el origen de los cultos ligado a indios y negros. El hecho de que la creación de las imágenes haya involucrado iniciativas de fieles pertenecientes a la población colonizada, incluyendo el trabajo concreto de artistas neófitos, fue sin dudas un factor clave en la tarea evangelizadora. Aunque en el surgimiento de las devociones fue decisiva también una cierta "invención" eclesiástica de los cultos, con intervenciones y reconocimientos de otros actores del poder colonial, el protagonismo de negros e indios cristianizados debió contribuir a que las imágenes -y por ellas, la religión católica- fueran aceptadas entre personas de esos mismos sectores socioétnicos. Sin embargo, el caso de Copacabana es iluminador en cuanto a las limitaciones de esa contribución: ambos sectores eran internamente diversos, con diferencias y tensiones -como aquellas entre urinsayas y anansayas - que incidían en las percepciones sobre sus creaciones religiosas.

Al mismo tiempo, esta observación sobre el origen neófito de las imágenes expresa hasta cierto punto una lógica más general del catolicismo. Nos referimos a aquella que suele atravesar distintas narrativas sobre santuarios y milagros en general, donde la creencia en las sacralidades católicas es sostenida con el aval de quienes -se supone- deberían cuestionarla (Estenssoro Fuchs 2003). En este sentido, el lugar de indios y negros durante la colonia podría equipararse al de cualquier grupo social percibido por la Iglesia católica como potencialmente crítico de sus creencias: desde el clásico caso de pastores y campesinos en Europa (cfr. Christian 1990; Fogelman 2003), hasta médicos y/o científicos en un contexto moderno (Costilla 2014).

6. En el proceso de progresiva aceptación de las imágenes coloniales analizadas, como anticipamos en el punto 3, fue decisivo el papel de los milagros. Éstos no solo persuadían eficazmente a los incrédulos, sino que también simbolizaban el aval divino hacia esas imágenes de factura local: en definitiva, hacia quienes las habían elaborado, acreditados como capaces de producir sacralidad a pesar de su condición social. En relación con esto podemos interpretar también los efectos específicos de los milagros reforzadores. Al ser éstos individuales y beneficiar a miembros de la elite hispano-criolla, es probable que hayan operado especialmente sobre personas de este sector social, quienes ante tales prodigios podían experimentar de un modo más cercano los favores de esas nuevas imágenes y afirmar su aprobación hacia ellas.

7. En cuanto al culto contemporáneo a la Virgen de San Nicolás, destaco el profundo desfasaje temporal que este caso expuso, en comparación con los ejemplos coloniales, entre la elaboración de la imagen en tanto objeto material y el origen de la devoción hacia ella. Ante tal observación resultó relevante distinguir y analizar estos dos procesos en cada uno de los casos. Dado nuestro interés por el momento en que surge el símbolo religioso en términos nativos, analizamos la situación específica del caso nicoleño. Como vimos, aunque el concepto de símbolo religioso no sea una categoría nativa, tomamos como parámetro el criterio de verdad nativo (ya sea institucional o devocional) en cuanto a la sacralidad del objeto. Es decir, cuando la imagen comienza a ser considerada milagrosa, eso implica una sacralización que la convierte en un símbolo especial. No solo por su carácter de representación sagrada, sino porque comienza a gestarse un símbolo que ya no es solo imagen material, sino también milagro y santuario (Costilla 2014, 2021). ${ }^{16}$ En este punto, si entendemos al símbolo dominante de un santuario católico como condensador de esos tres aspectos, podemos afirmar que en San Nicolás nació con las visiones de Gladys.

Al mismo tiempo, esta cuestión se vincula con el lugar protagónico que recibió la vidente, algo que observamos en las prácticas y representaciones nativas y de acuerdo a distintos aspectos del santuario (por ejemplo, la fecha de celebración). Gladys fue central porque fueron sus visiones las que le dieron forma, color, agencia y voz a la imagen de culto: una virgen que los sacerdotes locales asociaron con la escultura guardada en la catedral. Por eso, al verificar el papel de Gladys 
en tanto productora de la virgen-símbolo, planteamos la posibilidad de distinguir entre creadores materiales y simbólicos de una imagen de culto. Esto, una vez más, cobró notoriedad en la comparación, ya que los casos coloniales revelaron situaciones donde coincidieron completamente estas dos acciones creadoras: quienes realizaron las imágenes fueron quienes impulsaron su culto. Para continuar indagando posibles regularidades sobre esta cuestión, o sopesar su relevancia analítica, se vuelve necesario cotejar con otros casos semejantes de apariciones marianas durante el siglo XX (cfr. Ameigeiras y Suárez 2011) o con otros santuarios católicos en distintos contextos espacio-temporales.

Al concluir este trabajo, surge la pregunta sobre hasta qué punto podemos comparar las acciones de, por ejemplo, un negro cristianizado que vivía en la Lima virreinal del siglo XVII con las de una mujer criolla de familia católica que vivía en la ciudad de San Nicolás en los años 1980. Considero que, aún con sus distancias, es posible equiparar sus roles como devotos de imágenes católicas que comenzaban a descollar y como protagonistas -más o menos voluntarios- de la construcción de símbolos religiosos centrales para sus respectivas sociedades. De acuerdo a esto, el abordaje antropológico realizado definió un amplio horizonte comparativo -esperando sortear los riesgos de inconmensurabilidad acarreados por el caso nicoleño-, para focalizar en la dimensión simbólica y devocional de los santuarios católicos trascendiendo las distancias históricas y geográficas.

Una de las primeras limitaciones de tal aproximación, en la instancia de este trabajo, fue no poder profundizar en los pormenores de cada caso; pero frente al desafío de sintetizar la información empírica relevada, recurrimos a contemplar su tratamiento en publicaciones previas. Asimismo, se dificulta medir con exactitud el nivel en el que se inscriben las lógicas propuestas sobre la construcción de santuarios católicos latinoamericanos, entre aspectos locales, regionales y globales. Sin embargo, esperamos haber avanzado, al menos como estímulo para la discusión, en preguntas que podrán enriquecerse -y contrastarse- en dos sentidos: con la ampliación de datos sobre estos casos en futuras investigaciones y con estudios sobre otros santuarios, de acuerdo a distintas escalas de análisis. De hecho, la larga duración desarrollada en la tesis que enmarca este artículo fue reveladora por permitir rastrear en el tiempo los alcances de las interpretaciones realizadas sobre el surgimiento de los cultos.

En definitiva, propongo que a partir de un estudio comparado como el desarrollado en estas páginas, es posible contribuir a delinear un modelo antropológico para el análisis diacrónico de santuarios católicos latinoamericanos. Si hasta aquí se reconoce algún aporte, dicho modelo debe entenderse como una herramienta para formular hipótesis y plantear preguntas que puedan enriquecer el conocimiento antropológico dentro de este campo de estudios.

\section{AGRADECIMIENTOS}

A los doctores Carlos E. Zanolli y Pablo G. Wright, quienes dirigieron y acompañaron el desarrollo de mi tesis doctoral. Esta fue realizada con becas del CONICET y financiada con subsidios otorgados por la UBA y la ANPCYT, en el marco de proyectos UBACYT y PICT radicados en la Sección Etnohistoria del Instituto de Ciencias Antropológicas (FFyL, UBA). A la doctora Patricia Fogelman por sus múltiples aportes para mi investigación y sus análisis. A los evaluadores del manuscrito, por sus comentarios y sugerencias. Agradezco especialmente a la doctora Ana M. Lorandi (QEPD), quien impulsó el proyecto comparativo. In memoriam. 


\section{NOTAS}

1 La categoría "negro" ha sido resignificada entre la colonia y el desarrollo de los estados nación americanos, con influencias de los discursos científicos y activistas. La utilizaré contemplando su empleo en las fuentes coloniales y su uso contemporáneo como categoría de auto-adscripción, junto con las categorías de afro-limeños/descendientes (cfr. Arrelucea Barrantes y Cosamalón Aguilar 2015; Arrelucea Barrantes 2016). El mismo criterio seguiré para los conceptos "indio/indígena".

2 Dado el carácter comparativo de la tesis, con su amplitud histórico-geográfica, para este artículo realizamos una ajustada selección de las referencias bibliográficas empleadas en la investigación y de las citas documentales que respaldan las afirmaciones. Por las mismas razones, no podremos detenernos en una profundización de cada caso; remitiremos para ello a publicaciones previas y a la propia tesis donde cada uno de los santuarios fue descripto en detalle y analizado de manera particular.

3 La división tradicional entre anansaya y urinsaya, para las sociedades andinas, implicaba posiciones jerárquicas en términos organizativos, sociales y cósmicos, basadas en la dualidad arriba/abajo. Ambos conceptos correspondían a las dos parcialidades en las que las poblaciones se dividían, ocupando la de arriba, anansaya, una posición de preeminencia socio-política por sobre la de abajo, urinsaya (Costilla 2010:41).

4 Algunas fuentes coinciden en su origen angoleño (Banchero Castellano 1972), pero escritos más tempranos lo vinculaban a Guinea (Vásquez de Novoa [1766]1868:3) y Etiopía (Colmenares 1771:XXX).

5 Según investigaciones contemporáneas (Vargas Ugarte 1966; Banchero Castellano 1972:69-71), las figuras de la Virgen y la Magdalena debieron ser obras posteriores a 1651 y de otro pintor, aunque probablemente de la misma cofradía.

6 Incluso actualmente, la Iglesia católica boliviana lo ha convertido en un objeto de culto, propuesto para ser beatificado (Costilla 2014).

7 Esta institución fue perdiendo vitalidad por las exigencias que les imponían a los indios: "acudiendo a los mismos efectos que los de Roma, pagan tributo y acuden a las minas de Potosí y a otros trajines de Corregidores, con que se va acabando la gente y en breve se acabará tan santo instituto" (Calancha [1657] 1972:656).

8 Esta fecha correspondía al calendario cristiano, cuando se festeja la Exaltación de la Cruz; pero la fecha definitiva de celebración del culto, en el mes de octubre, quedó fijada desde el año 1687, luego del ya mencionado terremoto en la ciudad de Lima el día 20 de octubre. En ese momento se sacó al Cristo en procesión (gracias a una réplica ya existente en el santuario) y la fecha pasó a ser conmemorada por la primera procesión rogativa con la imagen y el significado del Cristo como protector frente a los sismos.

9 La Sociedad Mixta de Siderurgia Argentina (SOMISA) fue la primera y más importante industria siderúrgica nacional, fundada en 1960 y privatizada entre los años 1990 y 1992 (cfr. Rivero 2008; Flores 2013).

10 Entrevista realizada por la autora a un sacerdote local, rector del Santuario. 28 de noviembre de 2008, San Nicolás.

11 Entrevistas realizadas por la autora a una trabajadora local, catequista, 23 octubre 2010 y 8 junio 2012, San Nicolás.

12 Entre ese día de 1983 y el 11 de febrero de 1990, continuaron con una frecuencia casi diaria, hasta un total de 1804 mensajes. Aunque esa profusa cantidad constituía, según la Iglesia, un posible motivo para que se cuestionara su autenticidad, en 1990 el Obispado avaló la publicación, explicando que la cantidad se debía a una necesaria insistencia de la virgen como cualquier madre con sus hijos (Pérez 2007:64).

13 Objetos ofrecidos a la divinidad para agradecer una promesa o favor recibido. Son expuestos púbicamente en el santuario y, en tanto materializaciones de la gracia, se relacionan directamente con la persona devota y el favor concedido. Se constituyen, por tanto, en valiosos testimonios históricos y etnográficos (Rodríguez Becerra 1989; Ceriani Cernadas 2007).

14 Sobre ellas puede verse el trabajo de Muñoz Fernández 1989.

15 Este episodio era sumado a otras apariciones de la virgen en Potosí, en 1584, 1586 y 1588, las cuales inspiraron a "los tres hermanos Yupanqui" a pintar un "famoso lienzo" de la virgen en el cerro (Baltasar de Salas 1618 en Viscarra Fabre [1901]2010:139 [resaltado en original]). Este lienzo, del cual el cronista Viscarra Fabre incluye una ilustración ([1901]2010:138), habría dado origen al ciclo artístico de la virgen-cerro (Costilla 2014:350).

16 Esta propuesta teórica, del símbolo dominante en santuarios católicos como entidad tripartita, ha sido desarrollada en la tesis y trabajada en el citado artículo de 2021, actualmente en prensa. 
JuLIA CoSTILLA - ENTRETELONES DE SANTUARIOS CATÓLICOS: CREADORES DE SÍMBOLOS, MILAGROS Y ...

\section{REFERENCIAS BIBLIOGRÁFICAS}

Acosta Luna, O. I. (2011). Milagrosas imágenes marianas en el Nuevo Reino de Granada. Madrid-Frankfurt: Iberoamericana-Vervuert.

Ameigeiras A. y A. L. Suárez (2011). La Virgen del Cerro en Salta. Continuidades y singularidades respecto a las principales apariciones modernas y contemporáneas. Revista Cultura y Religión 5(2): 19-32.

Arrelucea Barrantes, M. (2016). Algunas reflexiones en torno a la esclavitud peruana y las identidades étnicas coloniales. Revista Latino americana de estudos avançados, 1 (1): 86-100.

Arrelucea Barrantes, M. y J. A. Cosamalón Aguilar (2015). La presencia afrodescendiente en el Perú. Siglos XVI-XX. Lima, Ministerio de Cultura.

Costilla, J. (2008). Símbolos en acción en relatos orales del NOA (1940-1998): la manifestación narrativa de las relaciones entre simbología religiosa, vida cotidiana y dinámica económica/ecológica. Revista de Investigaciones Folklóricas 23: 38-51.

Costilla, J. (2010). El milagro en la construcción del culto a Nuestra Señora de Copacabana (Virreinato del Perú 1582-1651). Estudios Atacameños. Arqueología y Antropología Surandinas 39: 35-56.

Costilla, J. (2013). El culto a la Virgen del Rosario en San Nicolás de los Arroyos (Argentina, 1983-2010): milagro y reconfiguración social. Runa 34 (2): 177-195.

Costilla, J. (2014). Luchas hermenéuticas, identidades y usos estratégicos del milagro en la elaboración y apropiación de cultos cristianos (siglos XVII a XXI- Perú, Bolivia y Argentina). Tesis Doctoral inédita, Facultad de Filosofía y Letras, Universidad de Buenos Aires. http://repositorio.filo.uba.ar/bitstream/handle/ filodigital/4608/uba_ffyl_t_2014_899476.pdf?sequence=1\&isAllowed=y

Costilla, J. (2015). "Guarda y custodia" en la Ciudad de los Reyes: la construcción colectiva del culto al Señor de los Milagros (Lima, siglos XVII-XVIII). Fronteras de la Historia 20 (2): 152-179.

Costilla, J. (2016). Itinerarios antropológicos para una etnohistoria comparada de la religión. Diálogo Andino 49: 299-309.

Costilla, J. (2021). De milagros, imágenes y santuarios: apropiaciones simbólicas en tres cultos católicos sudamericanos. Cultura \& Religión 15 (2). En prensa.

Banchero Castellano, R. (1972). Lima y el mural de Pachacamilla. Lima, Jurídica.

Bernand, C. y S. Gruzinski (1992). De la idolatría. Una arqueología de las ciencias religiosas. México, FCE.

Bloch, M. (1999) [1929]. Historia e historiadores. Madrid, Akal.

Bourdieu, P. (2009). La eficacia simbólica. Buenos Aires, Biblos.

Bovisio, M. A. y M. Penhos (2016). De waka a Virgen, de Virgen a waka: una reflexión sobre el estatuto de imágenes de culto coloniales desde la Antropología del Arte. Caiana, 8: 146-159.

Bruno, C. (1994). Historia de las manifestaciones de la Virgen. Rosario, Ediciones Didascolia.

Caballero Escorcia, B. A. (2015). La historia comparada. Un método para hacer Historia. Sociedady Discurso 28: 50-69. 
Relaciones de la Sociedad Argentina de Antropología 46 (2), julio-diciembre 2021: 699-723

Calancha, A. de la (1972) [1657]. Crónicas agustinianas del Perú. Tomo I. Biblioteca "Missionalia Hispánica" Vol XVII. Madrid, Consejo Superior de Investigaciones Científicas, Instituto “Enrique Florez", Departamento de Misionología Española.

Calavia Sáez, Ó. (2002). Las formas locales de la vida religiosa. Antropología e Historia de los Santuarios de La Rioja. Madrid, Consejo Superior de Investigaciones Científicas.

Candau, J. (2008). Memoria e identidad. Buenos Aires, Ediciones del Sol.

Carballo, C. (2009-10). Peregrinos católicos y religiosidad popular en Argentina. Estudios Socioterritoriales. Revista de Geografía 8: 53-69.

Carvalho, J. J. (2000). A religião como sistema simbólico. Uma atualização teórica. Série Antropologia 285: 2-17.

Ceriani Cernadas, C. (2017). 'Verdadero es lo hecho’: exvotos, materialidad y estética del deseo. En Ríos, J. (ed.), Por gracias recibidas: exvotos de joyeros contemporáneos: 22-30. Buenos Aires, Taller Eloi.

Christian, W. (1990). Apariciones en Castilla y Cataluña: siglos XIV-XVI. Madrid, Nerea.

Christian, W. (1991). Religiosidad local en la España de Felipe II. Madrid, Nerea.

Coelho Prado, M. L. (2012). América Latina: historia Comparada, historias conectadas, historia transnacional. Anuario de la Escuela de Historia 24 (3): 9-22.

Colmenares, F. (1771). El día deseado. Relación de la solemnidad con que se estrenó la iglesia del Santo Cristo de los Milagros [...]. Lima, Oficina de la Calle San Jacinto. Impreso.

Díaz Araya, A., L. Galdames Rosas y W. Muñoz Henríquez (2012). Santos patronos en los Andes. Imagen, símbolo y ritual en las fiestas religiosas del mundo andino colonial (siglos XVI-XVII). Alpha 35: 23-39.

Díez Taboada, J. M. (1989). La significación de los santuarios. En C. Álvarez Santaló, M. J. Buxó y S. Rodríguez Becerra (coords.), La religiosidad popular III: 268-281. Barcelona, Anthropos.

Di Stéfano, R. y L. Zanatta (2000). Historia de la Iglesia argentina: desde la conquista hasta fines del siglo $X X$. Buenos Aires, Mondadori.

El Comercio [Diario]. (1968). Esclavo de nombre Pedro Cruz pintó la Imagen del Señor de Pachacamilla. El Comercio, 16 de octubre de 1968. Documentoteca Benvenutto Murrieta (XR95.60), Universidad del Pacífico, Lima.

Eliade, M. (1994). Imágenes y símbolos. Barcelona, Planeta-Agostini.

El Norte [Diario] (1984). Nuevamente el 25. Cultos en honor a Nuestra Señora del Rosario de San Nicolás al cumplirse los 100 años. El Norte, 23 de noviembre de 1984: 13.

El Norte [Diario] (1986). La Historia de una aparición. El Norte, 25 de septiembre de 1986: 3.

Estenssoro Fuchs, J. C. (2003). Del paganismo a la santidad: la incorporación de los indios del Perú al catolicismo, 1532-1750. Lima, IFEA.

Ferro Medina, G. (2010). Guía de observación etnográfica y valoración cultural: santuarios y oficios. Apuntes 23 (1): 56-69. 
Julia Costilla - ENTRETELoNes de SANTUARIos CATólicos: CREAdores DE SÍMBOLOS, MiLAGRos Y ...

Flores, F. C. (2013). San Nicolás: entre el acero y las promesas. En P. Fogelman, M. Ceva y C. Touris, El culto mariano en Luján y San Nicolás. Religiosidad e Historia Regional: 119-141. Buenos Aires, Biblos.

Fogelman, P. (2003). Reconsideraciones sobre los orígenes del culto a la Virgen de Luján. Entrepasados, año XII, 23: 123-148.

Fogelman, P. (2006). Simulacros de la Virgen y refracciones del culto mariano en el Río de La Plata colonial. Eadem utraque Europa, Revista de Historia Cultural e Intelectual, año 2, 3: 11-34.

Freedberg, D. (1992). El poder de las imágenes. Madrid, Cátedra.

Frigerio, A. (2007). Repensando el monopolio religioso del catolicismo en la Argentina. En M. J. Carozzi, y C. Ceriani Cernadas (coords.), Ciencias sociales y religión en América Latina: 87-118. Buenos Aires, Biblos/ACSRM.

Gadamer, H.G. (1997). La hermenéutica de la sospecha. Cuaderno Gris. Época III, 2: 127-135.

Geertz, C. (1987). La interpretación de las culturas. México, Gedisa.

Gruzinski, S. (1995). La guerra de las imágenes. De Cristóbal Colón a "Blade Runner" (1492-2019). México, FCE.

Kuper, A. (2002). Comparison and contextualization: reflections on South Africa. En Gingrich, A. y R. G. Fox (eds.), Anthropology by Comparison: 143-166. London, Routledge.

Laurentín, R. (2006). María del Rosario de San Nicolás. Buenos Aires, San Pablo.

Liñán y Cisneros, M. de (1682). Nombramiento hecho por don Melchor de Liñán y Cisneros, arzobispo de Lima, en el bachiller Juan González de Montoya, presbítero, para que sea mayordomo y administre los bienes de la capilla del Santo Cristo de los Milagros... Archivo Arzobispal de Lima, Papeles Importantes 25:13. Ms.

Lizárraga, R. de (1968) [1605]. Descripción breve de toda la tierra del Perú, Tucumán, Río de la Plata y Chile. Madrid, Atlas.

Lorandi, A. M. (2012). ¿Etnohistoria, Antropología Histórica o simplemente historia? Memoria Americana 20 (1): $17-34$.

Lorandi, A. M. y A. E. Schaposchnik (1990). Los milagros de la Virgen del Valle y la colonización de la ciudad de Catamarca. Journal de la Société des Américanistes 76: 177-198.

Martín, E. (2007). Aportes al concepto de 'religiosidad popular': una revisión de la bibliografía argentina. En M. J. Carozzi y C. Ceriani Cernadas (coords.), Ciencias sociales y religión en América Latina. Perspectivas en debate:61-86. Buenos Aires, Biblos-ACSRM.

Marzal, M. (1999). La transformación religiosa peruana. En F. Armas Asín (comp.), La construcción de la Iglesia en los Andes (siglos XVI-XX): 143-172. San Miguel, Pontificia Universidad Católica del Perú.

Menezez, R. (2011). A imagem sagrada na era da reprodutibilidade técnica: sobre santinhos. Horizontes Antropológicos, año 17, 36: 43-65.

Meyer, B., D. Morgan, C. Paine y B. Plate (2011.) Introduction: key words in material religion. Material Religion, 7(1): 4-8.

Muñoz Fernández, A. (1989). El milagro como testimonio histórico: propuesta de una metodología para el 
estudio de la religiosidad popular. En C. Alvarez Santaló, et al. (coords.), La religiosidad popular. I: 164185. Barcelona, Anthropos.

Nicoletti, M. A. (2008). Indígenas y misioneros en la Patagonia. Huellas de los Salesianos en la cultura y en la religiosidad de los pueblos originarios. Buenos Aires, Continente.

Parker G. (2014). Pluralismo religioso y cambio de paradigma identitario en el campo político latinoamericano actual. En A. R. Ameigeiras (comp.) Símbolos, rituales religiosos e identidades nacionales. Los símbolos religiosos y los procesos de construcción política de identidades en Latinoamérica. 39-70. Buenos Aires, CLACSO.

Pérez, C. A. (2007). María del Rosario de San Nicolás. Soy tu Madre. Visión testimonial del acontecimiento mariano. San Nicolás, Centro de Difusión del Santuario.

Ramos Gavilán, A. fray (1976) [1621]. Historia de Nuestra señora de Copacabana. La Paz, Empresa editora "Universo".

Ricoeur, P. (1976). Introducción a la simbólica del mal. Buenos Aires, Megápolis.

Ricoeur, P. (1983). Freud: una interpretación de la cultura. México, Siglo XXI.

Rivero, C. (2008). Entre "la comunidad del acero" y la "comunidad de María”. Un análisis antropológico sobre los avatares sociopolíticos en San Nicolás. Buenos Aires, Antropofagia.

Rodriguez Becerra, S. (1989). Formas de la religiosidad popular. El exvoto: su valor histórico y etnográfico. En C. Álvarez Santaló, et al. (coords.), La religiosidad popular. I: 123-143. Barcelona, Anthropos.

Rodriguez Becerra, S. (2016). Santuarios y leyendas de apariciones de la Virgen María en el antiguo reino de Jaen. En A. Agudo Sanchiz y M. Cantón Delgado (eds.), Perspectivas antropológicas transculturales: Latinoamérica y Andalucía: 235-270. Madrid, Universidad Iberoamericana /Editorial Dharana.

Rodríguez López, A. (2021). Por una etnografía histórica de las religiosidades católicas heterodoxas. Sociedad y Religión, 56 (XXXI). ark:/s18537081/39rg0eaai

Roux, R. de (2014). La romanización de la Iglesia católica en América Latina: una estrategia de larga duración. Pro-posiçoes 25 (1), 73: 31-54.

Rubial, A. (2008). La invención de prodigios. La literatura hierofánica novohispana. Andamio 69: 121-132.

Sahlins, M. (1988). Islas de Historia. Madrid, Gedisa

Salles-Reese, V. (1997). From Viracocha to the Virgin of Copacabana. Austin, University of Texas Press.

Sánchez Rodríguez, S. (2002). Un Cristo Moreno "conquista” Lima: los arquitectos de la fama pública del Señor de los Milagros (1651-1771). En AA.VV., Etnicidad y discriminación racial en la historia del Perú: 65-93. Lima, PUCP/IRA/Banco Mundial.

Segato, R. L. (2016). Una paradoja del relativismo: el discurso racional de la antropología frente a lo sagrado. En F. Gorbach y M. Rufer, (In) disciplinar la investigación: archivo, trabajo de campo y escritura: 25-62. México, Siglo XXI.

Schwarz, F. (2008). Mitos, ritos, símbolos. Antropología de lo Sagrado. Buenos Aires, Biblos.

Steil, C. A. (2002). Peregrinação e Turismo Religioso: Tendências e paradigmas de interpretação. Estudios sobre Religión. Newsletter de la Asociación de Cientistas Sociales de la Religión en el Mercosur, 13: 1-5. 
Julia Costilla - ENTRETELoNes de SANTUARIos CATólicos: CREAdores DE SÍMBOLOS, MiLAGRos Y ...

Todorov, T. (2008). La conquista de América: el problema del otro. Buenos Aires, Siglo XXI.

Turner, V. (1980). La selva de los símbolos. Madrid, Siglo XXI.

Vargas Ugarte, R. (1966). Historia del Santo Cristo de los Milagros. Lima, Imprenta Sanmartí.

Vásquez De Novoa, P. (1868) [1766]. Compendio Histórico de la Prodigiosa Imagen del Santo Cristo de los Milagros. Lima, Imprenta de José María Concha.

Velasco Maillo, H. M. (1989). Las leyendas de hallazgos y de apariciones de imágenes. Un replanteamiento de la religiosidad popular como religiosidad local. En C. Álvarez Santaló et al. (coords.), La religiosidad popular. II: 401-410. Barcelona, Anthropos.

Viscarra Fabre, J. F. (2010) [1901]. Copacabana de los Incas. La Paz, Fundación Flavio Machicaco Viscarra y Fundación Cultural Banco Central.

Wachtel, N. (2001). El regreso de los antepasados. Los indios urus de Bolivia, del siglo XX al XVI. México DF, FCE.

Wright, P. (2015). "Yo tengo un don". Hermenéutica y antropología de la religión: entre la escucha y la sospecha de los símbolos. En J. M. Renold, (ed.), Religión: estudios antropológicos sobre sus problemáticas: 65-86. Buenos Aires, Biblos. 
